\title{
CHANGES IN BODY CONDITION OF HIGH-YIELDING DAIRY COWS
}

\section{Ž. Novaković, Lj. Sretenović, D. Ostojić-Andrić, M. M. Petrović, S. Aleksić, V. Pantelić, D.Nikšić}

\author{
Institute for Animal Husbandry, 11080, Belgrade-Zemun, Republic of Serbia \\ Corresponding author: zeljko.novakovic013@gmail.com \\ Original scientific paper
}

\begin{abstract}
Objective of the researchwas to investigate the level, structure and variability of realized differences between average values of body condition scores in high-yielding cows during most critical phases of production cycle. Realized differences were used as criterion for assessment of changes occuring in the cows' energy status through the level of increase or decrease of body condition. Realized average values of body condition scores, for individual and all body regions, within all studied phases of production cycle, deviated statistically very significantly $(\mathrm{p} \leq 0,01)$ from target values. Differences between average values of body condition scores according to phases of production cycle, for individual and all body regions, were statistically very significant $(\mathrm{p} \leq 0,01)$. Optimum body condition in dry period was realized by $48,76 \%$ cows, at calving $53,61 \%$, in the lactation peak $24,41 \%$ and in mid lactation $21,12 \%$. Average value of body condition scores at calving was higher by $0,18(-0,01$ to 0,72$)$ units compared to beginning of dry period, whereas at the lactation peak it was by $-1,26(-2,75$ to $0,41)$ units lower compared to calving, and in mid lactation compared to lactation peak it was higher by $0,18(-0,94$ to 0,85$)$ units. Within the distribution of achieved differences in body condition scores in the time from the beginning of dry period to calving in 346 cows or $96,11 \%$ of total number of animals $(n=360)$ increase of body condition score was realized ranging from $\leq 0,25$ units. Distribution of differences in body condition scores between calving and lactation peak showed that 243 cows or $71,48 \%$ of total 340 cows realized loss of body condition score of $>1,00$ units. Within distribution of differences in body condition scores between the lactation peak and mid lactation, 261 cows or $81,06 \%$ of total number of scored animals $(n=322)$ increased the body condition score in value of $\leq 0,25$ units. Study showed that, except in the dry period, changes of the body condition during other phases of production cycle weren't within the limits of optimum values. Realized results clearly showed the possibility of incidence of various production disorders, health issues and reproduction problems. Consequences are reflected also on longevity, life production and genetic progress. Realzied differences in average values of body condition scoreswere important basis for anticipation of potential
\end{abstract}


problems. In that regard, there are significant reserves in improvement of efficiency of management of body energy reserves in high yielding cows.

Key words: changes, body condition, production cycle phases

\section{Introduction}

The amount of available energy represents key factor on which the production of milk, fertility, health and welfare of animals depend. Good management of sources and exchange of energy is of essential importance for economical efficiency in cattle production. Net energy is the best, comprehesive way to express energy available to the animal. Modern norms in nutrition of highyielding dairy cows respect also the fact that one part of the energy required at the beginning of lactation should be provided from body reserves with necessary precondition that changes in body condition occur within physiologically acceptable limits. Lack of energy in critical periods of production can lead to serious disorders in production, health and reproduction, which consequently can mean great economical losses (Lotthamer, 1991; Šamanc et al., 2005).

Changes in the body mass of cows do not reflect adequately and suficiently precisely all differences in body energy reserves. Regular monitoring of the changes in body condition in that case represents important measure in control of the energy status of high yielding cows during production cycle. Differences in condition status of cows in most critical phases of production cycles were established using the adequate method for scoring of body condition (BCS), taking into consideration the greater importance in relation to absolutely determined level of scores according to production phases (Knight, 2001).

By continous scoring of body condition of cows conditions are created for anticipation of potential problems before their actual manifestation through drop in production, health and reproduction disorders. Body condition scoring is practical, cheap, efficient, fast, precise and functional method for establishment of body energy reserves in shape of subcutaneous fat tissue deposited in the pelvic and loin region, and tail head. Changes in body condition are related to changes in body mass (live weight) and its strucutre in high-yielding cows. Risk of expression and incidence of different problems at calving is significantly lower when cows are in optimum body condition (Wildman et al., 1982; Edmonson et al.,1989).

Changes in the condition status in the value of 1,0 units of BCS corresponds to body mass of cows of 56 (40-77) kilograms. In the post-calving period, during first 30 days of lactation, the maximum loss of body condition occures of approx. <1,0 units (Ferguson, 1994). During same period of early lactation, cows should loose $<1 \mathrm{~kg}$ of body mass per day. Adequate body reserves of fat tissue represent major condition for maximum increase of production of milk 
in the period of early lactation. Improvement of body condition by 1,0 unit in the dry period is associated with increase of quantity of milk by $545,5 \mathrm{~kg}$ in first 120 days of lactation (Domecq et al.,1997). Degree of loss of body mass during early lactation is directly associated with the condition of animal in the last stage of lactation and dry period. Changes in the body condition of high yielding cows during first weeks of lactation are important indicator of energy status and level of metabilic stress (Šamanc, 2005, Prodanović et al., 2012). Increase of body condition by 0,25 units over the limit of 3,75 units of BCS leads to decrease of intake of dry matter of daily diet of 1,5 to $2 \%$ (Roseler, 1998). Animals dried in fattening condition are of poor resistance in post-calving period (Lacatera et al., 2005; Van Knegsel et al., 2007). Cows with excess body condition regularly loose from 50 to $100 \mathrm{~kg}$ (often more) of body mass during early lactation. Increase of milk production in conditions of limited apetite during initial phase of lactation leads to incidence of negative energy balance (NEB), which is negative correlation to changes of body mass. Loss of body condition is greater and lasts longer during lactation of cows which have higher level of production of milk. Animals with prolonged NEB have cumulative loss of energy and are inclined to incidence of health disorders and reproduction problems (Gallo et al., 1996). In conditions of high milk production, intensive utilization of body energy reserves occurs as well as increased incidence of metabolic diseases in cows (Drackley, 2006). Incidence of clinical and subclinical ketosis is risk factor associated with abomasus dislocation, metritis, mastitis and ovarian cysts (Duffield, 2006). Changes in BCS are associated with cumulative negative energy balance, which is present as a pattern through entire production cycle, which to some extent explains increased incidence of metabilic disorders in older cows (Coffey et al.,2004). Cows in mid and late lactation gradually restore body reserves used during early lactation when they enter the period of positive energy balance (PEB). Changes in the body condition should be completed at an optimal level before the end of lactation (Ferguson et al., 1994).

Numerous researches have indicated the significant association between inadequate body condition and frequent reproduction disorders. Loss of 1,0 units of BCS, compared to optimal value of 3,50 units at calving, makes loss of $6-8 \%$ of cows' body mass during early lactation which often represents border value associated with incidence of various reproduction problems. Monitoring of the condition status of cows and stimulation of apetite is part of comprehensive strategy of encouriging of the cyclic ovarian activity and increased fertility in main herd. In case of cows which subsequent to calving are in inadequate and insatisfactory body condition, success in insemination is significantly reduced (Butler and Smith 1989; Drackley, 1999).

Objective of the research was to establish and investigate the level of realized differences in average values of BCS in high yielding cows during the most critical phases of production cycle. Realized differences were used as 
criterion for evaluation of changes in the energy status of cows through loss or increase of body condition. Also, the significance of differences between realized average values of BCS compared to target values was studied, as well as significance of differences between mean values of scores in different phases of production cycle. The strucutre of realized BCS from the point of view of optimal rank is reviewed and differences in BCS during all periods of production cycle analyzed.

\section{Material and Methods}

Object of study was realized level of change of body condition, as precise indicator of energy balance, observed through differences in average BCS values according to phases of production cycle in a herd of high yielding dairy cows of Holstein-Friesian breed. Study was realized on a sample comprising 363 cows. Cows within the sample realized in average 2,69 $(1,00-11,00)$ lactations. Average milk production in the last completed lactation was $6560 \mathrm{~kg}(3871-9390 \mathrm{~kg})$ with $245,4 \mathrm{~kg}(120,0-373,5 \mathrm{~kg})$ and $3,75 \%(3,49-4,18 \%)$ of milk fat. All animals within the sample were kept in same housing conditions (tie system), nutrition (complete diet supplemented with concentrate according to the milk performance), care and health protection, as well as exploitation. In the control of productivity, reproductive and health condition standard methods were used.

BCS of high yielding dairy cows was done according to pre-defined production cycle phases. Scores were presented at the level of average values with realized differences between all phases of production cycle. Realized BCS in the research was valued as indicator of the condition status of cows according to production phases and in relation to recommended values. Difference between average values of BCS within studied production phases was indicator of positive $(\uparrow)$, balanced $(=)$ or negative $(\downarrow)$ energy balance.

According to the plan od research, body condition was assessed visually according to method by Edmonson (1989). Score for each cow was done according to phases $(\mathrm{F})$ of production cycle in following way:

Table 1. Review of BCS according to phases of production cycle

\begin{tabular}{|c|c|c|}
\hline BCS number & Production cycle phase & $\begin{array}{c}\text { Designation of the } \\
\text { phase (F) }\end{array}$ \\
\hline 1 & Beginning of dry period & $\mathrm{F}_{1}$ \\
\hline 2 & Two days post calving & $\mathrm{F}_{2}$ \\
\hline 3 & Lactation peak (40 days) & $\mathrm{F}_{3}$ \\
\hline 4 & Mid lactation (150 days) & $\mathrm{F}_{4}$ \\
\hline
\end{tabular}


BCS system for high yielding dairy cows was created in form of a map with diagrams of all body regions within body regions determined for scoring with adequate text which precisely describes gradual changes of condition status according to pre-defined scale. Descriptive supplement of all BCS diagrams enables complete use of the map.

The map is precisely prepared for each body region (TR) and body field (TP). It includes all body region and fields which ar eimprotant in regard to awarding a total $\mathrm{BCS}$ for a cow. Three body region sare defined $\left(\mathrm{TR}_{1-3}\right)$ : loin $\left(\mathrm{TR}_{1}\right)$, rump $\left(\mathrm{TR}_{2}\right)$ tail head $\left(\mathrm{TR}_{3}\right)$. Within all three body regions there are in total eight body fields $\left(\mathrm{TP}_{1-8}\right)$. Each body field is scored separatelly. Scoring of body condition individually ori $\mathrm{n}$ general at the level of body regions, as well as at the level of mean values for all body regions is indicator of body condition of high yielding dairy cows.

Table 2. Review of body regions and fields usedi n BCS of cows

\begin{tabular}{|c|c|c|c|c|c|c|c|c|}
\hline Telesne regije / Body regions $\left(\mathrm{TR}_{1-3}\right)$ & \multicolumn{4}{|c|}{$\mathrm{TR}_{1}$} & \multicolumn{3}{|c|}{$\mathrm{TR}_{2}$} & $\mathrm{TR}_{3}$ \\
\hline Opis / Description $\left(\mathrm{TR}_{1-3}\right)$ & \multicolumn{4}{|c|}{ Slabine / Loin } & \multicolumn{3}{|c|}{ Karlica / Rump } & Koren repa \\
\hline Telesna polja / Body fields $\left(\mathrm{TP}_{1-8}\right)$ & $\mathrm{TP}_{1}$ & $\mathrm{TP}_{2}$ & $\mathrm{TP}_{3}$ & $\mathrm{TP}_{4}$ & $\mathrm{TP}_{5}$ & $\mathrm{TP}_{6}$ & $\mathrm{TP}_{7}$ & $\mathrm{TP}_{8}$ \\
\hline \multirow[t]{2}{*}{ Opis/Description $\left(\mathrm{TP}_{1-8}\right)$} & $\begin{array}{l}\text { Tmasti } \\
\text { nastavci }\end{array}$ & $\begin{array}{c}\text { Između } \\
\text { tmastih } \\
\text { nastavakai } \\
\text { poprečnih } \\
\text { nastavaka } \\
\end{array}$ & $\begin{array}{l}\text { Poprečni } \\
\text { nastavci }\end{array}$ & $\begin{array}{l}\text { Vešanje o } \\
\text { poprečne } \\
\text { nastavke }\end{array}$ & $\begin{array}{l}\text { Kukovii } \\
\text { sednjače }\end{array}$ & $\begin{array}{l}\text { Između } \\
\text { kukova i } \\
\text { sednjača }\end{array}$ & $\begin{array}{l}\text { Između } \\
\text { kukova }\end{array}$ & $\begin{array}{l}\text { Između korena } \\
\text { repa i sednjača }\end{array}$ \\
\hline & $\mathrm{A}$ & "I & 8 & 1 & & & & \\
\hline
\end{tabular}

By applying this method of scoring we continously monitor the condition, dynamics and changes in body condition of cows, individually and at group level, according to production cycle phases. In addition, this method provides possibility to precisely determine the changes in $\mathrm{BCs}$ in cow herd through realized differences in average values of scores according to phases of production cycle defined in the following way: 
Table 3. Review of examined differences between average BCS values according to production cycle phases

\begin{tabular}{|c|c|c|}
\hline $\begin{array}{c}\text { Differences between average BCS values according to phases } \\
\text { of production cycle }\end{array}$ & Differences & $\begin{array}{c}\text { Expected changes } \\
\text { of BCS (= or } \uparrow \text { or } \\
\downarrow)\end{array}$ \\
\hline Dry period - calving & $\mathrm{F}_{2}-\mathrm{F}_{1}$ & $=$ or $\uparrow$ \\
\hline Dry period - lactation peak & $\mathrm{F}_{3}-\mathrm{F}_{1}$ & $\downarrow$ \\
\hline Calving - lactation peak & $\mathrm{F}_{3}-\mathrm{F}_{2}$ & $\downarrow$ \\
\hline Dry period - mid lactation & $\mathrm{F}_{4}-\mathrm{F}_{1}$ & $\downarrow$ \\
\hline Calving - mid lactation & $\mathrm{F}_{4}-\mathrm{F}_{2}$ & $\downarrow$ \\
\hline Lactation peak - mid lactation & $\mathrm{F}_{4}-\mathrm{F}_{3}$ & $\uparrow$ \\
\hline
\end{tabular}

In regard to realized average values of BCS in different phases of production cycle, all cows were distributed within a scale with a range of 0,25 units $(\leq 0,25 ; 0,26-0,50 ; 0,51-0,75 ; 0,76-1,00 ;>1,00)$. Changes in the condition status of cows were quantitatively presented using absolute (number of animals) and relative (\% of animals) amount within said structure.

Analysis of collected data base was done using adequate mathematicalstatistical methods. Information on research results are given in tables using standard indicators of descriptive statistics. Selection of the procedure used in statistical analysis was determined by data characteristics, so in that regard methods for dependant samples were used. In this paper hypothesis on mean values were checked. Significance of differences for obtained average values compared to target values of BCS was verified using t-test. Results of Levene test showed that variance of data within studied phases of production cycle for each individual and total for all body regions were not homogenous, so significance of differences between average BCS values according to phases were tested using Friedman model of variance analysis (group test). Statistical analysis of experimental results was done using program package STATISTICA v. 6. StatSoft, Inc. (2003).

\section{Results and Discussion}

Achieved results of the study of body condition are presented through average BCS values in high yielding cows within each individual region and the level of all body regions according to production cycle phases (Table 4.). In general, from presented results it is obvious that realized average BCS values, for individual and all body regions, within all investigated production cycle phases, deviated statistically highly significantly $(\mathrm{p} \leq 0,01)$ from targt values. According to stated results, achieved condition status of cows was not within physiologically acceptable limits (Chilliard et al.,2000). 
Table 4. Average BCS of cows according to body regions and production cycle phases

\begin{tabular}{|c|c|c|c|c|}
\hline \multirow{2}{*}{ Body regions } & \multicolumn{4}{|c|}{$\mathrm{BCS}(\overline{\mathrm{X}} \pm \mathrm{SD})$} \\
\cline { 2 - 5 } & $\mathrm{F}_{1}$ & $\mathrm{~F}_{2}$ & $\mathrm{~F}_{3}$ & $\mathrm{~F}_{4}$ \\
\hline $\mathrm{TR}_{1}$ & $3,39 \pm 0,35$ & $3,56 \pm 0,37$ & $2,32 \pm 0,27$ & $2,52 \pm 0,35$ \\
\hline $\mathrm{p}$ & 0,000 & 0,005 & 0,000 & 0,000 \\
\hline $\mathrm{TR}_{2}$ & $3,39 \pm 0,36$ & $3,55 \pm 0,37$ & $2,31 \pm 0,27$ & $2,51 \pm 0,35$ \\
\hline $\mathrm{p}$ & 0,000 & 0,013 & 0,000 & 0,000 \\
\hline $\mathrm{TR}_{3}$ & $3,40 \pm 0,41$ & $3,58 \pm 0,42$ & $2,27 \pm 0,31$ & $2,47 \pm 0,39$ \\
\hline $\mathrm{p}$ & 0,000 & 0,000 & 0,000 & 0,000 \\
\hline $\mathrm{TR}_{1-3}$ & $3,39 \pm 0,37$ & $3,56 \pm 0,38$ & $2,30 \pm 0,27$ & $2,50 \pm 0,35$ \\
\hline $\mathrm{p}$ & 0,000 & 0,000 & 0,000 & 0,000 \\
\hline
\end{tabular}

In Table 5, structure of cows which were within the limits, below or above optimum BCS, according to production cycle phases, is presented:

Table 5. Review of number of cows within the limits, below or above optimum BCS, according to production cycle phases

\begin{tabular}{|c|c|c|c|c|c|}
\hline BCS & Number of cows & $\mathrm{F}_{1}$ & $\mathrm{~F}_{2}$ & $\mathrm{~F}_{3}$ & $\mathrm{~F}_{4}$ \\
\hline \multirow{2}{*}{$\begin{array}{c}\text { Above } \\
\text { optimum }\end{array}$} & $\mathrm{n}$ & 55 & 94 & 2 & 5 \\
\cline { 2 - 6 } & $\%$ & 15,15 & 26,11 & 0,59 & 1,55 \\
\hline \multirow{3}{*}{ Optimum } & $\mathrm{n}$ & 177 & 193 & 83 & 68 \\
\cline { 2 - 6 } & $\%$ & 48,76 & 53,61 & 24,41 & 21,12 \\
\hline \multirow{2}{*}{$\begin{array}{c}\text { Below } \\
\text { optimum }\end{array}$} & $\mathrm{n}$ & 131 & 73 & 255 & 249 \\
\cline { 2 - 6 } & $\%$ & 36,09 & 20,28 & 75,00 & 77,33 \\
\hline \multirow{2}{*}{ Total } & $\mathrm{n}$ & 363 & 360 & 340 & 322 \\
\cline { 2 - 6 } & $\%$ & 100,00 & 100,00 & 100,00 & 100,00 \\
\hline
\end{tabular}

From results presented in Table 5 it is apparent that in the dry period $48,76 \%$ of cows had optimum body condition, in pre-calving period $53,61 \%$, at lactation peak $24,41 \%$ and mid lactation $21,12 \%$. Ferguson et al.(1994) stated that total of 70 to $80 \%$ of cows should be within the optimum range of BCS. It is acceptable that $10-15 \%$ cows in herd can be outside the limits of optimum condition. If there are more than $15 \%$ of cows in extreme categories, this is a 
reliable indicator of present problems. Increase above said percentage requires application of corrective measures in the technological process. In the research realized by Gallo et al.(1996) average BCS value in Holstein cows in commercial dairy herds was $3,20(1,50-4,75)$ units, and in spite of wide variation range, most of scores were between 2,75 and 3,75 units, whereas only about $20 \%$ of scores were below or above these values.

Test of homogeneity and analysis of variance of BCS according to body regions and phases of production cycle are presented in the following table:

Table 6. Test of homogeneity and analysis of variance of BCS according to phases of production cycle

\begin{tabular}{|c|c|c|c|c|c|c|c|c|}
\hline \multirow{2}{*}{$\begin{array}{c}\text { Body } \\
\text { regions }\end{array}$} & \multicolumn{4}{|c|}{$\sim$} & \multicolumn{2}{c|}{ Levene test } & \multicolumn{2}{c|}{ ANOVA (Friedman ) } \\
\cline { 2 - 8 } & $\mathrm{F}_{1}$ & $\mathrm{~F}_{2}$ & $\mathrm{~F}_{3}$ & $\mathrm{~F}_{4}$ & $\mathrm{~F}$ & $\mathrm{p}$ & $\mathrm{H}$ & $\mathrm{p}$ \\
\hline $\mathrm{TR}_{1}$ & 3,39 & 3,56 & 2,32 & 2,52 & 9,521 & $<0,000$ & 922,461 & $<0,000$ \\
\hline $\mathrm{TR}_{2}$ & 3,39 & 3,55 & 2,31 & 2,51 & 11,362 & $<0,000$ & 924,911 & $<0,000$ \\
\hline $\mathrm{TR}_{3}$ & 3,40 & 3,58 & 2,27 & 2,47 & 18,050 & $<0,000$ & 900,386 & $<0,000$ \\
\hline $\mathrm{TR}_{1-3}$ & 3,39 & 3,56 & 2,30 & 2,50 & 12,190 & $<0,000$ & 928,019 & $<0,000$ \\
\hline
\end{tabular}

N.S.- $\mathrm{p}>0,05 \quad *$ - $\leq 0,05 \quad{ }^{*}$ - $-\mathrm{p} \leq 0,01$

In Table 6 , results of Levene test $(\mathrm{p} \leq 0,01)$ are presented showing that BCS variances according to studied phases of production cycle for each individual and all body regions were heterogenous. Considering this fact, significance of differences in average BCS was tested using the Friedman model of variance analysis. Analysis showed that differences between average BCS values according to production cycle phases, for individual and all body regions, were statistically very significant $(\mathrm{p} \leq 0,01)$. Obtained average values of 2,30 BCS units for all body regions $\left(\mathrm{TR}_{1-3}\right)$ at lactation peak $\left(\mathrm{F}_{3}\right)$ were similar to average value of 2,27 units of BCS which are in the same phase of production cycle obtained in the study by Hady et al.(1994). In the study realized on 429 cows of Holstein breed by Ruegg and Milton (1995) at calving, average BCS were obtained in the value of 3,23 units, whereas the minimum average score at lactation peak was 2,43 units. Average BCS for all periods of production cycle in Holstein cows had value of $3,02(1,20-4,80)$ units, at calving of primiparous cows 3,12 (2,30-4,20) and for multiparous $3,27(2,30-4,50)$, and for all cows after 60 days of lactation 2,78 $(1,20$ $4,50)$ and after 120 days of lactation 2,67 (1,20-3,80) units (Waltner et al.,1993). Within the research of association between BCS and daily body mass within first 150 days of lactation and reproduction characteristics of high yielding dairy cows in 787 Holstein primiparous cows, the average BCS at calving of 3,00 $(2,00-4,50)$ unitd was established, in 684 cows calving for the second time 3,00 (1,75-4,25) units and in 925 cows with three and more calvings 3,20 (2,00-4,75) units. Average 
BCS in the period from 40 to 60 days post-calving in 686 primiparous cows was $2,70(1,50-4,25)$ units, in 529 cows at their second calving 2,60 $(1,50-4,00)$ units, in 695 cows with three and more cows 2,60 (1,25-3,75) units (M. van Straten et al., 2009). Significant drop in the success of the first insemination occurs in limit values $\leq 2,50$ BCS units (Ferguson et al.,1994).

In the next table differences in average BCS values between production cycle phases are presented using the basic indicators of descriptive statistics:

Table 7. Differences in average BCS values between production cycle phases

\begin{tabular}{|c|c|c|c|c|c|c|}
\hline \multirow{2}{*}{ Indicators } & \multicolumn{7}{|c|}{ Differences in BCS } \\
\cline { 2 - 7 } & $\mathrm{F}_{2}-\mathrm{F}_{1}$ & $\mathrm{~F}_{3}-\mathrm{F}_{1}$ & $\mathrm{~F}_{3}-\mathrm{F}_{2}$ & $\mathrm{~F}_{4}-\mathrm{F}_{1}$ & $\mathrm{~F}_{4}-\mathrm{F}_{2}$ & $\mathrm{~F}_{4}-\mathrm{F}_{3}$ \\
\hline$\uparrow$ or $\downarrow$ & $\uparrow$ & $\downarrow$ & $\downarrow$ & $\downarrow$ & $\downarrow$ & $\uparrow$ \\
\hline $\bar{X}$ & 0,18 & $-1,08$ & $-1,26$ & $-0,89$ & $-1,07$ & 0,18 \\
\hline $\mathrm{n}$ & 360 & 340 & 340 & 322 & 322 & 322 \\
\hline $\mathrm{Max}$ & 0,72 & $-0,25$ & $-0,41$ & 0,00 & $-0,22$ & 0,85 \\
\hline $\mathrm{Min}$ & $-0,01$ & $-2,50$ & $-2,75$ & $-2,44$ & $-2,62$ & $-0,94$ \\
\hline $\mathrm{Sd}$ & 0,08 & 0,35 & 0,37 & 0,39 & 0,41 & 0,21 \\
\hline $\mathrm{Cv}$ & 43,98 & 32,61 & 29,04 & 43,90 & 37,95 & 116,29 \\
\hline
\end{tabular}

From results presented in Table 7 it is obvious that average score at calving $\left(\mathrm{F}_{2}\right)$ was higher by $0,18(-0,01$ to 0,72$)$ BCS units compared to beginning of dry period $\left(\mathrm{F}_{1}\right)$, which clearly confirms that the PEB has occurred expressed in form of deposited fat tissue during this period.

Average score at the lactation peak $\left(\mathrm{F}_{3}\right)$ was by $-1,26(-2,75$ to $-0,41) \mathrm{BCS}$ units lower compared to calving period $\left(\mathrm{F}_{2}\right)$. Stated difference indicates that high level of NEB was realized, leading to intensive loss of body reserves of fat tissue, and it is clearly apparent in lower average scores in the period of maximum daily production of milk. In favour of this is the fact that mean value in mid lactation $\left(\mathrm{F}_{4}\right)$ was by $-1,08(-2,50$ to $-0,25)$ BCS units lower compared to calving period $\left(\mathrm{F}_{2}\right)$. According to results found in literature sources, cows should not loose more than $1,0 \mathrm{BCS}$ units during early lactation. However, most of cows in the first 4 to 8 weeks of lactation loose from 25 to $75 \mathrm{~kg}$ of body mass, which corresponds to body reserves in the value of 0,50 to 1,50 BCS units (Buckley et al., 2003). Also, loss of body condition in the value of 1,0 BCS units equals the amount of mobilized body fat which corresponds to production of $600 \mathrm{~kg}$ of milk (Ferguson et al.,1994). On two farms of Holstein-Friesian cows, differences in average BCS values between dry period and $60^{\text {th }}$ day of lactation were realized on farm A in value of 0,55 units, and on farm B in the amount of 1,97 units (Šamanc et al., 2008). Also, cows loosing $\geq 1,25 \mathrm{BCS}$ units have significant problems in regard to conception after first insemination compared to those with moderate loss of $0,75-1,0$ BCS units 
(Gillund et al.,2001). Every 0,50 units of loss of body condition between calving and insemination corresponds to decrease in conception rate by $10-15 \%$. Loss of $>1,0$ BCS units significantly contributes to extanding of the service period and decreased conception rate (Bargo et al., 2002). Butler and Smith (1989), established very low conception rate $(17 \%)$ in first insemination in cows which lost $>1,00$ BCS units, whereas cows which lost post-calving $<0,5$ units had conception rate at the level of $65 \%$.

Average value of score in mid lactation $\left(\mathrm{F}_{4}\right)$ compared to lactation peak $\left(\mathrm{F}_{3}\right)$ was increased by $0,18(-0,94$ to 0,85$)$ BCS units and represented very small value of increase of condition status. This indicates low level of PEB which is significantly associated with complex problem of limited establishment of normal apetite, which directly contributes to reduced consumption of energy through daily diet. In case of all established differences in average BCS values according to production cycle phases there is high variability present.

In Table 8, results of the distribution of dry cows according to realized level of increase of condition stauts in BCS units are presented:

Table 8. Structure of increase of cows' $B C S$ in the time between the beginning of dry period $\left(F_{1}\right)$ and calving $\left(\mathrm{F}_{2}\right)$

\begin{tabular}{|c|c|c|c|c|}
\hline BCS units & $\begin{array}{c}\text { Number of } \\
\text { animals }\end{array}$ & $\begin{array}{c}\text { Number of animals } \\
\text { (cumulative) }\end{array}$ & $\%$ & $\begin{array}{c}\% \\
\text { (cumulative) }\end{array}$ \\
\hline$\leq 0,25$ & 346 & 346 & 96,11 & 96,11 \\
\hline $0,26-0,50$ & 11 & 357 & 3,06 & 99,17 \\
\hline $0,51-0,75$ & 3 & 360 & 0,83 & 100,00 \\
\hline $0,76-1,00$ & 0 & 360 & 0 & 100,00 \\
\hline$>1,00$ & 0 & 360 & 0 & 100,00 \\
\hline Total & 360 & - & 100,00 & - \\
\hline
\end{tabular}

In the previous table 8 , review of structure related to improvement of the condition status of cows in the period from the beginning of dry period $\left(\mathrm{F}_{1}\right)$ to calving $\left(\mathrm{F}_{2}\right)$ according to pre-defined ranges of $0,25 \mathrm{BCS}$ units. Cows were distributed in corresponding score ranges based on realized difference in condition status. Most of cows in respect to realized difference in form of improvement of the condition status, was in the range of $\leq 0,25 \mathrm{BCS}$ units. This level of increase of BCS was realized by 346 cows or $96,11 \%$ of total number of animals $(n=360)$. Differences in scores in this period are in concordance with recommendations which point out the significance of sustaining of present or modest increase of body condition status in this phase of production cycle (Ferguson, 1994). 
In Table 9, results of the distribution of losses in the condition status of cows are presented in BCS units at the beginning of lactation:

Table 9. Structure of losses of BCS in the period between calving $\left(F_{2}\right)$ and lactation peak $\left(F_{3}\right)$

\begin{tabular}{|c|c|c|c|c|}
\hline BCS units & Number of animals & $\begin{array}{c}\text { Number of animals } \\
\text { (cumulative) }\end{array}$ & $\%$ & $\begin{array}{c}\% \\
\text { (cumulative) }\end{array}$ \\
\hline$\leq 0,25$ & 0 & 0 & 0 & 0 \\
\hline $0,26-0,50$ & 1 & 1 & 0,29 & 0,29 \\
\hline $0,51-0,75$ & 13 & 14 & 3,82 & 4,11 \\
\hline $0,76-1,00$ & 83 & 97 & 24,41 & 28,52 \\
\hline$>1,00$ & 243 & 340 & 71,48 & 100,00 \\
\hline Total & 340 & - & 100,00 & - \\
\hline
\end{tabular}

Results presented in Table 9 indicate that in regard to drop in body condition between calving $\left(\mathrm{F}_{2}\right)$ and lactation peak $\left(\mathrm{F}_{3}\right)$, most cows lost body condition in the value of $>1,00$ BCS units. This level of decrease of body condition was realized by 243 cows or $71,48 \%$ of total number of animals $(n=340)$. Loss of body condition in the range from 0,76 to 1,00 BCS units was realized by 83 animals or $24,41 \%$, whereas the least animals were in other ranges. Distribution of differences in average scores between these two pof production cycle indicates high level of realized body condition in this lactation period. Drop in the body condition in this phase of production was realized at high level. In the period of early lactation, loss of body condition should be below 1,0 BCS units and it is necessary that cow realized body condition of $>2,5$ units (Ferguson, 1996). In the study of the associazion between the body condition and production of milk in Holstein cows (Domecq et al.,1997) result have been presented showing that multiparous Holstein cows had average BCS at the beginning of dry period in the value of 2,77 units, whereas at the calving it was 2,66 units. The lowest value of the BCS level occurred between the $4^{\text {th }}$ and $8^{\text {th }}$ week of lactation. The average loss in this period was 0,62 BCS units. Change in BCS in primiparous cows was similar, but the drop in body condition was not so low like in multiparous animals. Holstein cows lost 0,59 BCS units in the period between calving and moment when the lowest value of the condition status was recorded, whereas in jersey cows, in the same period, loss of 0,29 units was established (Rastani et al., 2001). Losses in body condition in the lactation peak, at the lowest value, compared to average values pre-calving, were 0,55 for primiparous cows and 0,71 units for multiparous cows. Average loss of BCS for all cows within the study was 0,62 units (Sakaguchi, 2009). 
Review of distribution of differences in BCS units during restoring of body condition of cows in the period from lactation peak to mid-lactation is presented in next table:

Table 10. Structure of BCS increase in the period from lactation peak $\left(F_{3}\right)$ to mid lactation $\left(F_{4}\right)$

\begin{tabular}{|c|c|c|c|c|}
\hline BCS units & $\begin{array}{c}\text { Number of } \\
\text { animals }\end{array}$ & $\begin{array}{c}\text { Number of animals } \\
\text { (cumulative) }\end{array}$ & $\%$ & $\begin{array}{c}\% \\
\text { (cumulative) }\end{array}$ \\
\hline$\leq 0,25$ & 261 & 261 & 81,06 & 81,06 \\
\hline $0,26-0,50$ & 49 & 310 & 15,21 & 96,28 \\
\hline $0,51-0,75$ & 11 & 321 & 3,41 & 99,70 \\
\hline $0,76-1,00$ & 1 & 322 & 0,32 & 100,00 \\
\hline$>1,00$ & 0 & 322 & 0 & 100,00 \\
\hline Total & 322 & - & 100 & - \\
\hline
\end{tabular}

Based on results presented in Table 10 it is apparent that in regard to distribution of differences in BCS between lactation peak $\left(\mathrm{F}_{3}\right)$ and mid lactation $\left(\mathrm{F}_{4}\right)$, most cows increased their body condition in the value of $\leq 0,25 \mathrm{BCS}$ units. Stated amount of body condition increase was realized by 261 cows or $81,06 \%$ of total number of scored animals $(\mathrm{n}=322)$, whereas in other ranges, 61 animals or $18,94 \%$ were recorded. Distribution of realized differences clearly indicates very modest increase of body condition during this period of production cycle. Ruegg and Milton (1995), in Holstein cows, have established the value of restored body condition of 0,13 units per each 6 weeks from the moment when BCS was at the minimum. Ferguson (1996) stated that the value of gradually restored body condition in the period of 6 weeks when energy balance turned positive was 0,20 units.

\section{Conclusion}

Realized average values of scores of body condition, for individual body regions and total, and within all studied production cycle phases, deviated statistically highly significantly $(p \leq 0,01)$ from target values. Differences between average values of body condition scores according to phases of production cycle, and within individual and total body regions, were statistically very significant $(p \leq 0,01)$. During the dry period, positive energy balance in form of increase of body condition of cows was realized at the satisfactory level. In the period between calving and lactation peak, intensive loss of body fat tissue reserves, i.e. high level of negative energy balance was realized, which brought about the lower average 
score level in the period of maximum daily production of milk. During the period from lactation peak to mid lactation, very modest value of improvement of body condition was recorded, which precisely indicates the low level of positive energy balance. In all established average differences in body condition scores between all studied phases of production cycle, high variability was present. The study showed that, except in the dry period, changes in body condition during other production cycle phases weren't within the optimum values. Realized differences in average values of body condition scores were important basis for antitcipation of potential problems before their actual manifestation. Realized results clearly pointed out to the possibility of incidence of various disorders in production, health and reproduction. Consequences are reflected on longevity, life production and genetic progress. In that regard, there are significant reserves for improvement of efficiency in management of body reserves of energy in high yielding dairy cows.

\section{Acknowledgment}

Research was financed by the Ministry of Education and Science of Republic of Serbia, project TR 31053.

\section{Promene telesne kondicije visokomlečnih krava}

\section{Ž. Novaković, Lj. Sretenović, D. Ostojić-Andrić, M. M. Petrović, S. Aleksić, V.} Pantelić, D.Nikšić

\section{Rezime}

Realizovane prosečne vrednosti ocena telesne kondicije krava, za pojedinačne i sve telesne regije, u okviru svih ispitivanih faza proizvodnog ciklusa, statistički vrlo značajno $(\mathrm{p} \leq 0,01)$ su odstupale od ciljnih vrednosti. Razlike između prosečnih vrednosti ocena telesne kondicije po fazama proizvodnog ciklusa, u okviru svake pojedinačne i svih telesnih regija, bile su statistički vrlo značajne $(p \leq 0,01)$. Optimalnu telesnu kondiciju na zasušenju ostvarilo je $48,76 \%$ krava, na teljenju $53,61 \%$, u vrhu laktacije $24,41 \%$ i na sredini laktacije $21,12 \%$. Prosečna vrednost ocena telesne kondicije krava kod teljenja bila je veća za 0,18 (-0,01 do $0,72)$ jedinica u odnosu na početak zasušenja. Srednja vrednost ocena telesne kondicije krava na vrhu laktacije bila je za $-1,26(-2,75$ do $-0,41)$ jedinica manja $u$ odnosu na teljenje. Prosečna vrednost ocena na sredini u odnosu na vrh laktacije bila je povećana za $0,18(-0,94$ do 0,85$)$ jedinica. Kod svih utvrđenih prosečnih razlika u ocenama telesne kondicije između svih ispitivanih faza proizvodnog ciklusa bila je prisutna visoka varijabilnost. $U$ okviru distribucije ostvarenih razlika 
ocena telesne kondicije u periodu između početka zasušenja i teljenja kod 346 krave ili $96,11 \%$ od ukupnog broja grla $(n=360)$ ostvareno je povećanje telesne kondicije $\mathrm{u}$ intervalu $\leq 0,25$ jedinica. Raspodela razlika ocena telesne kondicije između teljenja i vrha laktacije kod ukupno 340 krava pokazala je da su 243 krave ili $71,48 \%$ ostvarile gubitak telesne kondicije u iznosu $>1,00$ jedinice. $U$ okviru raspodele razlika u ocenama telesne kondicije između vrha i sredine laktacije 261 krava ili $81,06 \%$ od ukupnog broja ocenjenih grla $(\mathrm{n}=322)$ povećale su telesnu kondiciju u vrednosti $\leq 0,25$ jedinica.

\section{Literatura:}

BARGO F., MULLER, L.D., DELAHOY J.E., CASSIDY T.W. (2002): Performance of High Producing Dairy Cows with Three Different Feeding Systems Combining Pasture and Total Mixed Rations, J. Dairy Sci. 85: 2948-2963.

BUCKLEY F., O'SULLIVAN K., MEE J.F., EVANS R.D., DILLON P. (2003): Relationships Among Milk Yield, Body Condition, Cow Weight, and Reproduction in Spring-Calved Holstein-Friesians. J. Dairy Sci. 86: 2308-2319.

BUTLER, W.R., SMITH R.D.(1989): Interrelationships between energy balance and postpartum reproductive function in dairy cattle. J. Dairy Sci. 72: 767-783.

CHILLIARD Y., FERLAY A., FAULCONNIER Y., BONNET M., ROUEL J., BOCQUIER F. (2000): Adipose tissue metabolism and its role in adaptations to undernutrition in ruminants. Proceedings of the Nutrition Society, 59, 127-134.

COFFEY M.P., SIMM G., OLDHAM J.D., HILL W.G., BROTHERSTONE S. (2004): Genotype and Diet Effects on Energy Balance in the First Three Lactations of Dairy Cows. J. Dairy Sci. 87: 4318-4326.

DOMECQ J.J., SKIDMORE A.L., LLOYD J.W., KANEENE J.B. (1997): Relationship between body condition scores and milk yield in a large dairy herd of high yielding Holstein cows. J. Dairy Sci. 80: 101-112.

DRACKLEY J.K. (1999): Biology of Dairy Cows During the Transition Period: the Final Frontier.

J. Dairy Sci 82: 2259-2273.

DRACKLEY J.K. (2006): Advences in transition cow biology: new frontiers in production diseases. V: Production diseases in farm animals, $12^{\text {th }}$ international conference. Joshi N.P., Herdt T.H., Wageningen Academic Publishers: 24-34.

DUFFIELD T.F. (2006): Epidemiology of subclinical production diseases in dairy cows with an emphasis on ketosis. V: Production diseases in farm animals, 12th international conference. Joshi N.P., Herdt T.H., Wageningen Academic Publishers: 126-135.

EDMONSON A.J., LEAN I.J., WEAVER L.D., FARVER T., WEBSTER G. (1989): A body condition scoring chart for Holstein dairy cows. J. Dairy Sci 72: 68-78. 
FERGUSON J.D., GALLIGAN D.T., THOMSEN N. (1994): Principal Descriptors of Body Condition Score in Holstein Cows, J. Dairy Sci. 77:2695-2703.

FERGUSON J.D. (1996): Implementation of a body condition scoring program in dairy herds. In Feeding and managing the transition cow. Proceedings of the Penn Annual Conference, University of Pennsylvania, Center for Animal Health and Productivity, Kennett Square, PA.

GALLO L., CARNIER P., CASSANDRO M., MANTOVANI R., BAILONI L., CONTIERO B., BILTANTE G. (1996): Change in Body Condition Score of Holstein Cows as Affected by Parity and Mature Equivalent Milk Yield. J. Dairy Sci. 79:1004-1015.

GILLUND P., REKSEN O., GROHN Y. T., KARLBERG K. (2001): Body Condition Related to Ketosis and Reproductive Performance in Norwegian Dairy Cows, J. Dairy Sci. 84:1390-1396.

HADY P.J., DOMECQ J.J., KANEENE J.B. (1994): Frequency and in Dairy Cattle Precision of Body Condition Scoring, J. Dairy Sci 77:1543-1547.

KNIGHT C.H. (2001): Lactation and gestation in dairy cows: flexibility avoids nutritional extremes. Proceedings of the Nutrition Society, 60, 527-537.

LACATERA N., SCALIA D., BERNABUCCI U., RONCHI B., PIRAZZI D., NARDONE A. (2005): Lymphocyte Functions in Overconditioned Cows Around Parturition. J. Dairy Sci. 88: 2010-2016.

LOTTHAMMER K.H. (1991): Uticaj i posledice neizbalansirane ishrane na zdravlje i plodnost mlečnih krava. Zbornik predavanja 20-tog seminara za inovaciju znanja veterinara, str. 71-120. Fakultet veterinarske medicine, Beograd.

M. VAN STRATEN, SHPIGEL N. Y., FRIGER M. (2009): Associations among patterns in daily body weight, body condition scoring, and reproductive performance in high-producing dairy cows. J. Dairy Sci. $92: 4375-4385$.

PRODANOVIĆ R., SLADOJEVIĆ Ž., KIROVSKI D., VUJANAC I., IVETIĆ V., SAVIĆ B., KURELJUŠIĆ B., STEVANČEVIĆ M. (2012): Use of metabolic profiles and body condition scoring for the assessment of energy status of dairy cows. Biotechnology in Animal Husbandry 28 (1), p 25- 32.

RASTANI R.R., ANDREW S.M., ZINN S.A., SNIFFEN C.J. (2001): Body Composition and Estimated Tissue Energy Balance in Jersey and Holstein Cows During Early Lactation. J. Dairy Sci. 84:1201-1209.

ROSELER D.K. (1998): Dry matter intake of dairy cattle: Prediction, performance and profit. Proceedings: Tri-State Dairy Nutrition Conference, Fort Wayne, IN, 97120.

RUEGG P.L., MILTON R.L. (1995): Body condition scores of Holstein cows on Prince Edward Island, Canada: Relationship with yield, reproductive performance and disease. J. Dairy Sci. 78: 552-564.

SAKAGUCHI M. (2009): Differences between body condition scores and body weight changes in postpartum dairy cows in relation to parity and reproductive indices. Can. Vet. J. 50(6): 649-656. 
ŠAMANC H., SINOVEC Z., ADAMOVIĆ M., GRUBIĆ G. (2005): Uloga ishrane u etiopatogenezi metabolizma visoko-mlečnih krava. 4 simpozijum "Ishrana, reprodukcija i zaštita zdravlja goveda", str. 3-18, Subotica.

ŠAMANC H., STOJIĆ V., DANIJELA KIROVSKI, JOVANOVIĆ M., CERNESCU H., VUJANAC I., PRODANOVIĆ R. (2008): Uticaj telesne kondicije krava na učestalost i stepen zamašćenja jetre. Vet. glasnik 62 (1-2) 3 - 12.

VAN KNEGSEL A.T.M., DE VRIES REILINGH G., MEULENBERG S., VAN DEN BRAND H., DIJKSTRA J., KEMP B., PARMENTIER H.K. (2007): Natural Antibodies Related to Energy Balance in Early Lactation Dairy Cows. J. Dairy Sci. 90:5490-5498.

WALTNER S.S., MCNAMARA J.P., HILLERS J.K. (1993): Relationships of Body Condition Score to Production Variables in High Producing Holstein Dairy Cattle, J. Dairy Sci 76: 3410-3419.

WILDMAN E.E., JONES G.M., WAGNER P.E., BOWMAN R.L., TROUTT H.F., LESCH T.N. (1982): A dairy cow body condition scoring system and its relationship to selected production characteristics. J. Dairy Sci. 65: 495-501. 